\title{
Acid-base and metabolic disturbances in fulminant hepatic failure
}

\author{
C. O. RECORD ${ }^{1}$, R. A. ILES, R. D. COHEN, AND ROGER WILLIAMS \\ From the Liver Unit, King's College Hospital Medical School, London, and the Metabolic and Endocrine \\ Unit, The London Hospital Medical College, London
}

SUMMARY In 28 patients with fulminant hepatic failure alkalaemia was present in 49 of a total of 65 observations. Alkalaemia was due primarily to a low $\mathrm{Pa}, \mathrm{CO}_{2}$ in 30 instances and to raised plasma bicarbonate in 16 instances. Blood lactate, pyruvate, and acetoacetate were significantly raised, and in individual cases, blood citrate, succinate, and fumarate were elevated. Blood citrate rose progressively as the clinical condition worsened. Metabolic acidosis was only present in four patients. In three of these patients, all of whom had taken an overdose of paracetamol, the acidosis was severe, present before the onset of clinical hepatic failure, and associated with hypoglycaemia and mild hypotension. In two of these patients the acidosis was shown to be due to accumulation of lactic acid. Plasma free fatty acid concentrations were elevated out of proportion to the degree of ketosis.

Acid-base disturbances are well recognized in hepatic coma due to chronic liver disease (Vanamee, Poppell, Glickman, Randall, and Roberts, 1956; Heinemann, Emirgil, and Mijnssen, 1960; Reinicke, Friis, and Müllertz, 1963; Zieve, 1966) and in fulminant hepatic failure hyperventilation and both respiratory and metabolic alkalosis are seen (Rueff, Sicot, and Benhamou, 1969; Opolon, Hadchouel, Del Corso, and Caroli, 1970). Lactic acidosis has been noted in both acute (Perret, Enrico, Montani, and Pappalardo, 1967) and chronic liver disease (Mulhausen, Eichenholz, and Blumentals, 1967; Smadja, Opolon, Hadchouel, Touboul, and Caroli, 1972) and liver dysfunction was thought to be of aetiological importance in 18 of the 71 cases of lactic acidosis described by Tranquada (1964). Elevations in the concentrations in blood of pyruvate (Amatuzio and Nesbitt, 1950; Seligson, McCormick, and Sborov, 1952; Dawson, de Groote, Rosenthal, and Sherlock, 1957), 2-oxoglutarate (Seligson et al, 1952; Dawson et al, 1957), citrate (Iber, Rosen, Levenson, and Chalmers, 1957), free fatty acids (Mortiaux and Dawson, 1961), and triglyceride (Mendenhall and Mortiaux, 1962) are also recognized in liver disease and in cirrhosis fasting ketone body concentrations are lower than normal (Recant, 1956).

There is little information, however, on the

'Present address: The London Hospital, London E1 1BB.

Received for publication 21 November 1974. metabolic disturbances which occur in fulminant hepatic failure and their correlation with changes in acid-base balance. In this paper, we report acidbase abnormalities, blood lactate and pyruvate concentrations, together with the concentrations in blood of some tricarboxylic acid cycle intermediates, ketone bodies, free fatty acids, and triglycerides in 28 patients with this condition.

\section{Patients and Methods}

Observations were made at daily intervals on 28 patients, all of whom were in grade 3 or 4 hepatic coma (Trey, Burns, and Saunders, 1966) at some stage. In 13 patients this was due to liver damage resulting from an overdose of paracetamol and in eight patients to viral hepatitis. In the remainder liver damage was attributed to other drugs and hepatotoxins. Twelve patients recovered.

Treatment was essentially as described by Williams (1974) and this included $10 \% \mathrm{w} / \mathrm{v}$ dextrose (approximately 3 litres/day) by continuous infusion through a central venous pressure catheter. Some patients received intravenous heparin by continuous infusion (Rake, Flute, Parnell, and Williams, 1970), but fructose was not used and none were treated by exchange transfusion. Arterial blood was collected from an indwelling arteriovenous shunt or from the femoral artery by direct puncture for blood gas determinations and arterial or central venous blood 
was taken simultaneously for estimation of lactate and other constituents. Blood collected from patients who were in only minor grades of hepatic coma was always taken from an arteriovenous shunt. Observations were discontinued if the patient required intermittent positive pressure ventilation or developed more than transient hypotension (systolic blood pressure $<13.3 \mathrm{kPa}(100 \mathrm{~mm} \mathrm{Hg}))$; the only exception to this rule was in three patients with severe acidosis described below in a separate group.

The results were compared with those obtained from fasted normal subjects who had received intravenous glucose $(0.5 \mathrm{~g} / \mathrm{kg})$ intravenously 40 minutes previously. However, for citrate, fumarate, succinate, and 3-hydroxybutyrate the control observations were obtained from normal resting subjects four hours after meals.

\section{CHEMICAL METHODS}

Arterial pH, $\mathrm{PO}_{2}$, and $\mathrm{PCO}_{2}$ were determined directly using apparatus supplied by Radiometer (model BMS 3, Radiometer, Copenhagen). The following blood metabolites were determined on a neutralized perchloric acid extract of whole blood by standard enzymatic techniques: lactate and pyruvate (Hohorst, Kreutz, and Bücher, 1959); 2-oxoglutarate (Bergmeyer and Bernt, 1963); acetoacetate (Williamson, Mellanby, and Krebs, 1962); ammonia (Kirsten, Gerez, and Kirsten, 1964). Citrate, fumarate, succinate, and 3-hydroxybutyrate were determined by gas chromatography (Barnett, Cohen, Tassopoulos, Turtle, Dimitriadou, and Fraser, 1968) on $6 \mathrm{ml}$ whole blood samples and plasma free fatty acids (FFA) by colorimetry (Itaya and Ui, 1965). Plasma triglycerides were determined as glycerol released after alkaline hydrolysis (Eggstein and Kreutz, 1966).

\section{STATISTICAL METHODS}

The distribution of values in the 'control' and patient groups was examined by calculation of the coefficients of skewness and curtosis (Snedecor and Cochran, 1967). For all measurements the distributions of values in the control groups were not distinguishable from normal, whereas, except in the case of triglycerides those in the patient group were not normal. The values in the control groups have therefore been expressed as means \pm SEM and those in the patient group as median and range. Because of the departure from normality in the patient group the distribution-independent MannWhitney $U$ test was employed in comparisons (Siegel, 1956). When correlation coefficients were calculated, Spearman's rank correlation test was used (Siegel, 1956), since the distribution of data departed from bivariate normality.

\section{Results}

ACID-BASE ANALYSIS

A low $\mathrm{Pa}, \mathrm{CO}_{2}(<4.8 \mathrm{kPa}(36 \mathrm{~mm} \mathrm{Hg}))$ was the commonest finding and accounted for 38 of the 65 observations (fig 1). On eight occasions the blood pH was in the normal range $(7 \cdot 37-7 \cdot 42)$ whereas in the remainder a low $\mathrm{Pa}, \mathrm{CO}_{2}$ was associated with alkalaemia.

A metabolic alkalosis $\left(\mathrm{pH}>7.44 ; \mathrm{Pa}, \mathrm{CO}_{2}\right.$ 4.8-5.9 $\mathrm{kPa}(36-44 \mathrm{~mm} \mathrm{Hg})$ ) was present on 16 occasions (fig 2). On three occasions alkalaemia was associated with a slightly elevated $\mathrm{Pa}, \mathrm{CO}_{2}$ while on seven occasions blood gas analysis was within normal limits. The mean arterial oxygen concentration was $12.25 \pm 0.93 \mathrm{kPa}(92 \pm 7 \mathrm{~mm} \mathrm{Hg}, 64$ observations), and on only three occasions were values less than $9.3 \mathrm{kPa}(70 \mathrm{~mm} \mathrm{Hg})$.

Metabolic acidosis was seen on only one occasion, apart from in an apparently distinct group of three patients. These presented $48 \mathrm{~h}$ after paracetamol overdose with severe metabolic acidosis $(\mathrm{pH} 7 \cdot 14$ 7.27) but in these cases this was accompanied by mild hypotension, peripheral vasoconstriction, and dehydration. Marked hypoglycaemia was also present (blood sugar $<1.1 \mathrm{mmol} / 1(20 \mathrm{mg} / 100 \mathrm{ml})$ ) and this

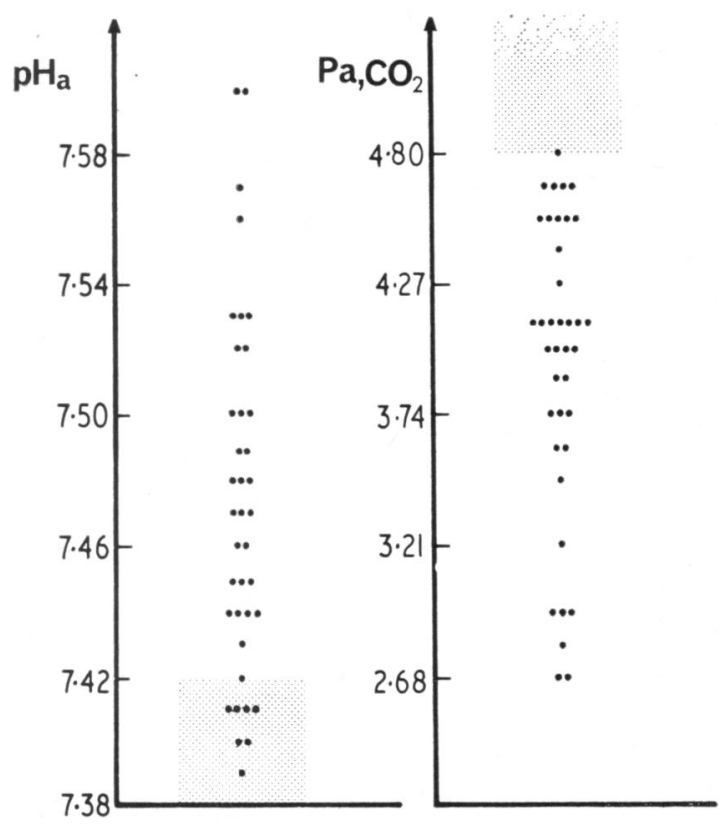

Fig 1 Arterial $\mathrm{pH}$ and $\mathrm{PCO}_{2}$ on 21 patients with fulminant hepatic failure with a low $\mathrm{Pa}, \mathrm{CO}_{2}$. The shaded area shows the normal range. $\mathrm{PCO}_{2}$ expressed in $\mathbf{k P a}$. 


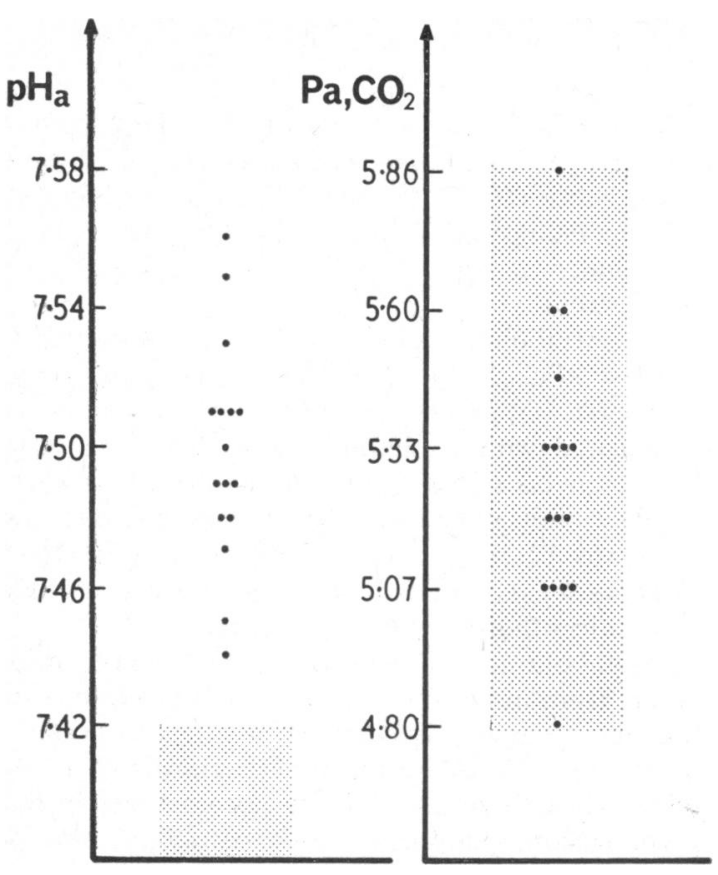

Fig 2 Arterial $p \mathrm{H}$ and $\mathrm{PCO}_{2}$ on 10 patients with fulminant hepatic failure with a metabolic alkalosis. The shaded area shows the normal range. $\mathrm{PCO}_{2}$ expressed in $\mathrm{kPa}$. resulted in drowsiness which improved after the administration of glucose. These patients were treated with intravenous fluids, including sodium bicarbonate, but subsequently developed severe hepatic encephalopathy and alkalaemia and two died.

\section{BLOOD LACTATE AND PYRUVATE CONCENTRATIONS}

The blood lactate concentrations, in all patients, with the exception of the severely acidotic group, ranged from 1.03 to $15.4 \mathrm{mmol} / 1$ (median 3.01 $\mathrm{mmol} / \mathrm{l}, \mathrm{n}=61$ ). Blood pyruvate concentration in the same patients ranged from 0.50 to $0.64 \mathrm{mmol} / 1$ (median $0.203 \mathrm{mmol} / \mathrm{l}, \mathrm{n}=60$ ). The blood [lactate]/ [pyruvate] ratio was slightly elevated. There were no significant differences in blood lactate or pyruvate concentration between any of the groups with different acid-base disturbances (table II) although a weak positive correlation $(P<0.05-$ Spearman's rank correlation test) between lactate and $\mathrm{pH}$ was seen (fig 3). No correlation, however, was seen between lactate and the grade of hepatic coma nor between lactate and $\mathrm{Pa}, \mathrm{CO}_{2}$. Blood lactate and pyruvate were measured in two of the three patients described above with severe metabolic acidosis and hypoglycaemia. In these patients, at the height of the acidosis, blood lactate concentrations were 20.2 and $12.7 \mathrm{mmol} / 1$ ([lactate]/[pyruvate] 34 and 21 respectively) but fell to 4.7 and $10.8 \mathrm{mmol} / 1$ respect-

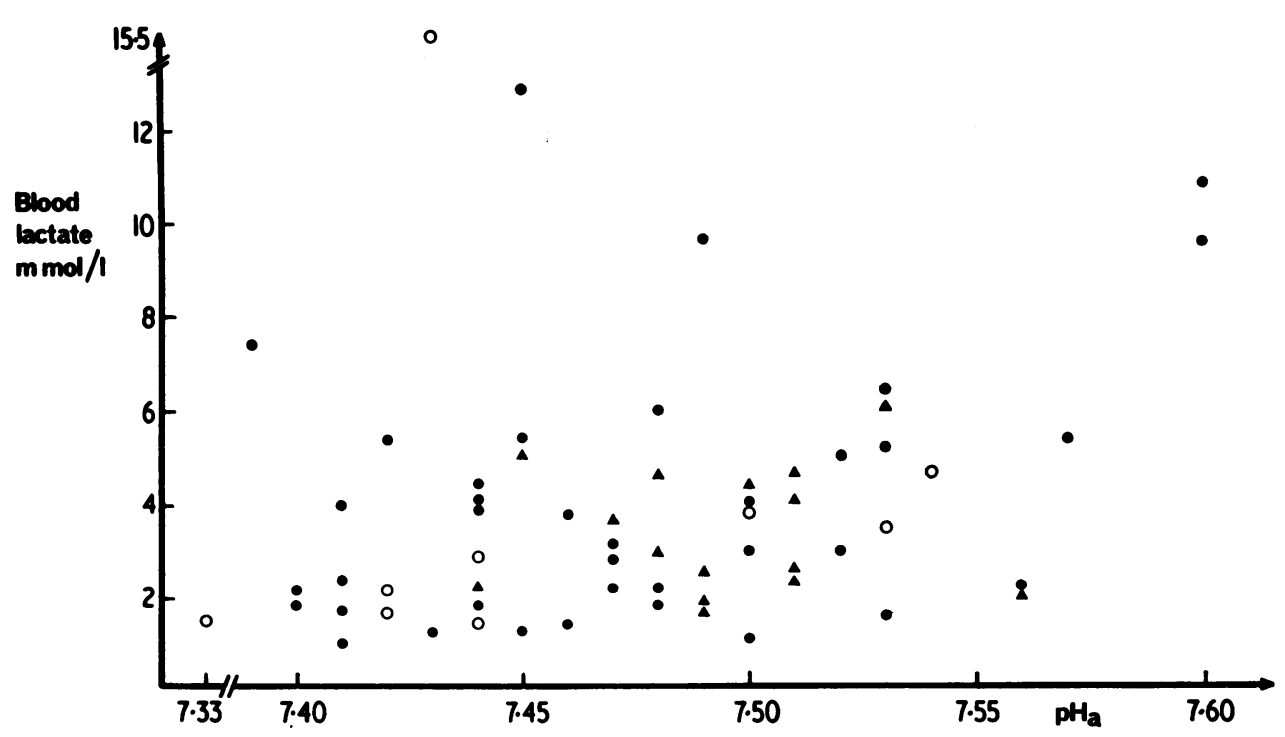

Fig 3 Relationship between blood lactate concentration and arterial pH in 28 patients with fulminant hepatic failure. Alkalaemia with normal $\mathrm{Pa}, \mathrm{CO}_{2} \Delta$; low $\mathrm{Pa}, \mathrm{CO}_{2} \mathrm{O}$; other patterns $\mathrm{O}$. 


\begin{tabular}{|c|c|c|c|c|c|}
\hline & \multicolumn{2}{|c|}{ Fulminant Hepatic Failure } & \multicolumn{2}{|l|}{ Control } & \multirow[t]{2}{*}{$P^{8}$ (two-tailed) } \\
\hline & $\begin{array}{l}\text { No. of } \\
\text { Observations }\end{array}$ & Median and Range & $\begin{array}{l}\text { No. of } \\
\text { Observations }\end{array}$ & $M e a n \pm S E M$ & \\
\hline $\begin{array}{l}\text { Ammonia } \\
\text { Lactate } \\
\text { Pyruvate } \\
\text { 2-Oxoglutarate } \\
\text { Citrate } \\
\text { Fumarate } \\
\text { Succinate } \\
\text { 3-Hydroxybutyrate } \\
\text { Acetoacetate } \\
\text { Free fatty acids } \\
\text { Triglycerides } \\
\text { [Lactate]/[Pyruvate] }\end{array}$ & $\begin{array}{l}59 \\
61 \\
60 \\
56 \\
42 \\
46 \\
46 \\
43 \\
54 \\
18 \\
20 \\
59\end{array}$ & $\begin{array}{l}0.235(0.087-0.717) \\
3.01 \quad(1.03-15.4) \\
0.203(0.053-0.643) \\
0.020(0.006-0.052) \\
0.130(0.018-0.730) \\
0.014(<0.01-0.092) \\
0.009(<0.008-0.174) \\
0.043(0.010-0.144) \\
0.022(0.002-0.151) \\
0.86(0.61-2.16) \\
0.68 \quad(0.36-1.99) \\
15.9 \quad(6.8-45 \cdot 1)\end{array}$ & $\begin{array}{r}8 \\
22 \\
22 \\
22 \\
9 \\
10 \\
10 \\
16 \\
21 \\
16 \\
16 \\
22\end{array}$ & $\begin{array}{l}0.044 \pm 0.005 \\
1.18 \pm 0.05 \\
0.106 \pm 0.004 \\
0.011 \pm 0.001 \\
0.069 \pm 0.013 \\
<0.01^{4} \\
<0.008^{4} \\
0.031 \pm 0.004 \\
0.016 \pm 0.002 \\
0.55 \pm 0.08 \\
0.86 \pm 0.079 \\
11.3 \pm 0.41\end{array}$ & $\begin{array}{r}<0.01 \\
<0.01 \\
<0.01 \\
<0.01 \\
N^{3}\end{array}$ \\
\hline
\end{tabular}

Table I Blood concentrations of some metabolites in patients with fulminant hepatic failure and in control subjects $(\mathrm{mmol} / \mathrm{l})^{1}$

${ }^{1}$ The three patients with metabolic acidosis and hypoglycaemia are excluded since mild circulatory insufficiency was present.

2Statistical comparisons based on the Mann-Whitney $U$ test.

NS-not significant.

"Values represent lower limit of sensitivity of the method.

ively after treatment with intravenous fluids including bicarbonate and glucose.

BLOOD KETONE BODY, FFA, AND

TRIGLYCERIDE CONCENTRATIONS

3-Hydroxybutyrate (43 observations on 16 patients) and acetoacetate concentrations (54 observations on 28 patients) were slightly higher than in control subjects but for the former this difference was not significant. Free fatty acid concentrations were also significantly raised (18 patients) to twice the control value (table I) and a significant elevation was also seen when heparin-treated patients (7) were excluded. Triglyceride concentrations were normal (table I).

BLOOD 2-OXOGLUTARATE, CITRATE, SUCCINATE, AND FUMARATE CONCENTRATIONS

Blood 2-oxoglutarate concentrations were measured on 56 occasions and were significantly raised compared with controls (table I). Blood citrate concentrations (42 observations on 16 patients) were not significantly elevated but when followed in individual patients appeared to rise as the clinical condition worsened (fig 4). Succinate and fumarate concentrations although low were in most instances measurable, in contrast to the situation in normal subjects in whom the concentrations of these metabolites are too low for quantification. Whereas in the control

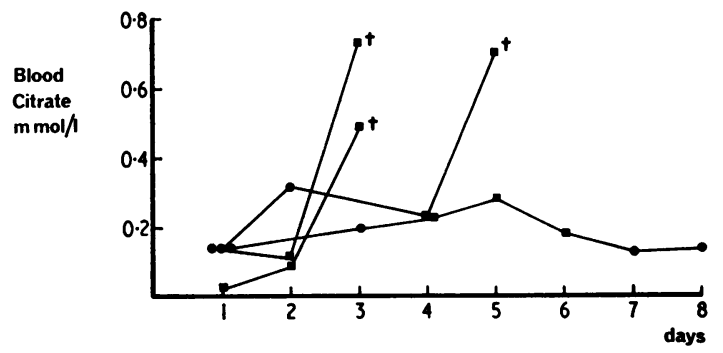

Fig 4 Sequential blood citrate concentrations in three patients who died $(+)$ from fulminant hepatic failure at varying intervals after observations were discontinued and one who survived. Grade 4 hepatic coma $\square$; lesser grades 0 .

\begin{tabular}{|c|c|c|c|c|}
\hline \multirow[t]{2}{*}{ Acid-base Group } & \multicolumn{2}{|c|}{ Lactate } & \multicolumn{2}{|c|}{ Pyruvate } \\
\hline & No. & Concentration (mmol/l) & No. & Concentration (mmol/l) \\
\hline
\end{tabular}

Table II Blood concentrations of lactate and pyruvate in 28 patients with fulminant hepatic failure grouped according to acid-base status ${ }^{1}$

${ }^{1}$ Values are expressed as median and range. There is no significant difference between any pair of groups (Mann-Whitney $U$ test). 
subjects blood succinate and fumarate concentrations were below the limit of sensitivity of the method, in the patients fumarate concentrations were not measurable in only 10 out of 46 instances and succinate concentrations in only 14 out of 46 instances. In one subject blood succinate was strikingly raised $(0 \cdot 174 \mathrm{mmol} / \mathrm{l})$.

\section{BLOOD AMMONIA}

Blood ammonia concentrations were significantly increased (table I) but bore only a poor correlation with the grade of hepatic coma.

\section{Discussion}

A low $\mathrm{Pa}, \mathrm{CO}_{2}$ with alkalaemia was the most common acid-base disturbance seen in fulminant hepatic failure. This may result from a direct stimulation of the respiratory centre by toxins which accumulate in liver failure but the nature of such toxic substances has not been identified.

A metabolic alkalosis was also frequently seen. This could have been due to potassium deficiency and a decrease in total body potassium has been described in hepatitis (Casey, Summerskill, and Orvis, 1965). Plasma potassium concentrations were not consistently decreased, but these data are insufficient upon which to assess potassium status. An inability to alkalinize the urine is recognized in the presence of hypovolaemia (Seldin and Rector, 1972) but in patients with fulminant hepatic failure the plasma volume is increased (Wilkinson, 1974). In those patients in whom it was measured, the urinary $\mathrm{pH}$ was inappropriately low for the systemic alkalosis present and the contribution of the kidney to the metabolic alkalosis requires further evaluation. Gastric aspiration and vomiting were thought to be the principal cause of the metabolic alkalosis in the patients described by Opolon et al (1970) but significant gastric aspiration occurred in only one patient with metabolic alkalosis in the present series. Alternative sources of metabolic alkalosis which should be considered are accumulation of bases in the circulation, movement of hydrogen ions into the intracellular space, or failure of normal metabolic pumping of hydrogen ions from cells.

Blood lactate concentrations were elevated on average three- to four-fold in patients with fulminant hepatic failure. Such an elevation could have been mediated through a $\mathrm{pH}$-dependent stimulation of glycolysis particularly in the subjects with respiratory alkalosis, which is associated with a rise in intracellular $\mathbf{~ p H}$ in all tissues studied experimentally under these conditions. The activity of the ratelimiting glycolytic enzyme, phosphofructokinase, is markedly stimulated by a rise in pH (Ui, 1966;
Zborowska-Sluis and Dossetor, 1967). Many organs, including skeletal muscle, heart, and erythrocytes could contribute to the raised blood lactate concentrations in these circumstances. However, only a weak correlation was observed between $\mathrm{pH}$ and blood lactate, so that although an increase in glycolysis may be contributory it cannot be the only factor involved. The concentrations of gluconeogenic amino acids are also considerably increased in patients with fulminant hepatic failure (Record, Buxton, Chase, Curzon, and Williams, 1974) and these, together with the elevated lactate concentrations and the frequent occurrence of hypoglycaemia in this condition, suggests a decrease in hepatic gluconeogenesis.

The range of elevation in blood lactate was from just above normal to $20.2 \mathrm{mmol} / \mathrm{l}$ but only in the two patients with acidosis and hypoglycaemia in whom blood lactate was measured was metabolic acidosis definitely due to the accumulation of lactate. Pyruvate concentrations were significantly elevated in patients with fulminant hepatic failure and the [lactate]/[pyruvate] ratio was also increased. The [lactate]/[pyruvate] ratio might be elevated because of a rise in cytoplasmic [free NADH]/[free NAD] or a fall in intracellular $\mathrm{pH}$ though many other factors are also involved. The increased [lactate]/[pyruvate] ratio is unlikely to be due to tissue hypoxia, as, with the exception of the three patients with metabolic acidosis and hypoglycaemia, shock was absent and oxygen partial pressures in arterial blood were within normal limits.

Free fatty acid concentrations were considerably elevated. The patients with fulminant hepatic failure were maintained on intravenous glucose and under these fed conditions one would expect free fatty acid concentrations to be low as insulin inhibits adipose tissue lipolysis. Although continuous heparin administration may have contributed to the fatty acid elevation by its action on clearing factor lipase this is unlikely to provide the complete explanation as only some patients were treated with this agent. There is normally a constant relationship between plasma free fatty acid and ketone body concentrations as a major determinant of the rate of ketogenesis is availability of this substrate (Williamson, 1970). Since ketogenesis occurs only in the liver the high FFA/ketone body ratio observed suggests an impairment in this process in the liver. Plasma triglyceride levels are often related to those of free fatty acids (eg, Adams, Kissebah, Harrigan, Stokes, and Wynn, 1974) and the normal plasma triglycerides seen in these patients in the presence of marked elevation of plasma free fatty acids could indicate impaired triglyceride synthesis similar to that of ketone bodies. For both precursor-product pairs (FFA/ketones and 
FFA/triglycerides), these conclusions must be tentative since increased removal of blood ketones and triglycerides could also account for the findings.

Lactic acidosis has been reported in fulminant hepatic failure by Smadja et al (1972); most of their patients were in circulatory failure. Our results emphasize the rarity of lactic acidosis in the absence of peripheral circulatory failure. However, three patients with inadequate peripheral circulation, all of whom had taken paracetamol, did develop reversible severe metabolic acidosis and hypoglycaemia before the clinical features of hepatic failure had developed. Although blood lactate was only measured in two of these it seems probable that lactic acidosis was also present in the third. The association with hypoglycaemia strongly suggests that the syndrome was due to failure of hepatic gluconeogenesis.

Succinate and fumarate concentrations were often slightly increased; only in one patient was a gross elevation in blood succinate seen. A marked rise in blood succinate concentration occurs in patients who are hypotensive and hypoxic due both to an increase in intracellular succinate concentration and to a breakdown of the normal permeability barrier to succinate at the cell membrane (Iles, Barnett, Strunin, Simpson, and Cohen, 1972). Since hypoxia was unlikely to have been present in the patients described the mildly elevated blood succinate concentrations observed may represent an increase in cell membrane permeability in surviving hepatocytes in this condition.

\section{References}

Adams, P. W., Kissebah, A. H., Harrigan, P., Stokes, T., and Wynn, V. (1974). The kinetics of plasma free fatty acid and triglyceride transport in patients with idiopathic hypertriglyceridaemia and their relation to carbohydrate metabolism. Europ. J. clin. Invest., 4, 149-161.

Amatuzio, D. S., and Nesbitt, S. (1950). A study of pyruvic acid in the blood and spinal fluid of patients with liver disease with and without hepatic coma. J. clin. Invest., 29, 1486-1490.

Barnett, D., Cohen, R. D., Tassopoulos, C. N., Turtle, J. R., Dimitriadou, A., and Fraser, T. R. (1968). A method for estimation of Krebs cycle and related intermediates in animal tissues by gas chromatography. Analyt. Biochem., 26, 68-84.

Bergmeyer, H. U., and Bernt, E. (1963). In Methods of Enzymatic Analysis, edited by H. U. Bergmeyer, p. 324. Verlag Chemie, Weinheim. Academic Press, New York and London.

Casey, T. H., Summerskill, W. H. J., and Orvis, A. L. (1965). Body and serum potassium in liver disease: 1 . Relationship to hepatic function and associated factors. Gastroenterology, 48, 198-207.

Dawson, A. M., De Groote, J., Rosenthal, W. S., and Sherlock, S. (1957). Blood pyruvic-acid and alpha-ketoglutaric-acid levels in liver disease and hepatic coma. Lancet, 1, 392-396.

Eggstein, M., and Kreutz, F. H. (1966). Eine neue Bestimmung der Neutralfette im Blutserum und Gewebe. 1, Prinzip, Durchfuhrung und Besprechung der Methode. Klin. Wschr., 44, 262 267.

Heinemann, H. O., Emirgil, C., and Mijnssen, J. P. (1960). Hyperventilation and arterial hypoxemia in cirrhosis of the liver. Amer. J. Med., 28, 239-246.

Hohorst, H. J., Kreutz, F. H., and Bücher, T. (1959). Über Meta- bolitgehalte und Metaboltikonzentrationen in der Leber der Ratte. Biochem. Z., 332, 18-46.

Iber, F. L., Rosen, H., Levenson, S. H., and Chalmers, T. C. (1957). The plasma amino acids in patients with liver failure. J. Lab. clin. Med., 50, 417-425.

Iles, R. A., Barnett, D., Strunin, L., Strunin, J. M., Simpson, B. R., and Cohen, R. D. (1972). The effect of hypoxia on succinate metabolism in man and the isolated perfused dog liver. Clin. Sci., 42, 35-45.

Itaya, K., and Ui, M. (1965). Colorimetric determination of free fatty acids in biological fluids. J. Lipid Res., 6, 16-20.

Kirsten, E., Gerez, C., and Kirsten, R. (1963). Eine enzymatische Mikrobestimmung des ammoniaks, geeignet fur Extrakte tierischer Gewebe und Flussigkeiten. Biochem. Z., 337, 312-319.

Mendenhall, C. L., and Mortiaux, A. (1962). Alterations in serum triglyceride levels in liver disease. Gastroenterology, 42, 684685.

Mortiaux, A., and Dawson, A. M. (1961). Plasma free fatty acid in liver disease. Gut, 2, 304-309.

Mulhausen, R., Eichenholz, A., and Blumentals, A. (1967). Acidbase disturbances in patients with cirrhosis of the liver. Medicine (Baltimore), 46, 185-189.

Opolon, P., Hadchouel, P., Del Corso, A., and Caroli, J. (1970). Ammoniémie et équilibre acido- basique au cours de l'atrophie aiguë du foie. Ann. Méd. Int., 121, 1-15.

Perret, A., Enrico, J. F., Montani, S., and Pappalardo, G. (1967). Le rôle de la nécrose hépatique dans la pathogénèse de l'acidose lactique 'spontanée'. Schweiz. med. Wschr., 97, 666-671.

Rake, M. O., Flute, P. T., Pannell, G., and Williams, R. (1970). Intravascular coagulation in acute hepatic necrosis. Lancet, 1, 533-537.

Recant, L. (1956). Diminished ketogenesis in liver injury. J. Lab. clin. Med., 48, 165-170.

Record, C. O., Buxton, B., Chase, R., Curzon, G., and Williams, R. (1974). Amino acid concentrations in fulminant hepatic failure and their role in the pathogenesis of hepatic coma. (Submitted for publication).

Reinicke, V., Friis, T., and Müllertz, S. (1963). Respiratory alkalosis and decreased oxygen saturation of arterial blood in patients with chronic hepatitis. Scand. J. clin. Lab. Invest., 15, 29-36.

Rueff, B., Sicot, C., and Benhamou, J. P. (1969). Les hépatites aiguës comateuses: semiologie et évolution. In Journées de Réanimation de l'Hópital Claude Bernard, Part I, pp. 131-143. Arnette, Paris.

Siegel, S. (1956). Non-Parametric Statistics for the Behavioral Sciences. McGraw-Hill, New York.

Seldin, D. W., and Rector, F. C., Jr. (1972). The generation and maintenance of metabolic alkalosis. Kidney Int., 1, 306-321.

Seligson, D., McCormick, G. J., and Sborov, V. (1952). Blood ketoglutarate and pyruvate in liver disease. J. clin. Invest., 31, 661.

Smadja, M., Opolon, P., Hadchouel, P., Touboul, J. P., and Caroli, J. (1972). Les acidoses lactiques au cours des hépatopathies. Med. Chir. Dig., 1, 179-184.

Snedecor, G. W., and Cochran, W. G. (1967). Statistical Methods, 6th ed. Iowa State University Press, Ames, Iowa.

Tranquada, R. (1964). Lactic acidosis. Calif. Med., 101, 450-461.

Trey, C, Burns, D G., and Saunders, S. J. (1966). Treatment of hepatic coma by exchange blood transfusion. New Engl. J. Med., 274, 473-481.

Ui, M. (1966). A role of phosphofructokinase on pH-dependent regulation of glycolysis. Biochim. biophys. Acta (Amst.), 124, 310-322.

Vanamee, P., Poppell, J. W., Glicksman, A. S., Randall, H. T., and Roberts, K. E. (1956). Respiratory alkalosis in hepatic coma. Arch. intern. Med., 97, 762-767.

Wilkinson, S. Unpublished observations.

Williams, R. (1974). Fulminant viral hepatitis. Clin. Gastroent., 3, 419-436.

Williamson, D. H. (1970). Metabolism and function of ketone bodies, In Essays in Cell Metabolism, edited by W. Bartley, H. L. Kornberg, and J. R. Quayle, pp. 257-281. Wiley, London and New York.

Williamson, D. H., Mellanby, J., and Krebs, H. A. (1962). The determination of $\mathrm{D}(-)$-3-hydroxybutyric acid and acetoacetic acid in blood. Biochem. J., 82, 90-98.

Zborowska-Sluis, D. T., and Dossetor, J. B. (1967). Hyperlactatemia of hyperventilation. J. appl. Physiol., 22, 746-755.

Zieve, L. (1966). Pathogenesis of hepatic coma. Arch. intern. Med., 118. 211-223. 